\title{
Introduction to the special issue "Old worlds, new ideas. A tribute to Albert van der Meulen"
}

\author{
Lars W. van den Hoek Ostende ${ }^{1} \cdot$ Pablo Pelaez-Campomanes ${ }^{2} \cdot$ Wilma Wessels $^{3}$
}

Received: 3 July 2015 / Accepted: 8 July 2015 / Published online: 13 August 2015

(C) Senckenberg Gesellschaft für Naturforschung and Springer-Verlag Berlin Heidelberg 2015

Science advances knowledge. There are multiple ways to achieve this. In a science like palaeontology, every new locality, and sometimes even just a single fossil, brings new information which allows us to confirm our ideas, or sometimes necessitates their revision. Much of the advancement stems from research using familiar methods to gather new data. Alternatively, we can look at data in a new way, which often leads to leaps in our knowledge. Albert Jan van der Meulen has always been a master in finding such original solutions, being one of the rare scientists who kept reinventing himself throughout his career. Therefore, this special issue in his honour on the occasion of his 75th birthday is aptly called "Old worlds, new ideas".

For his $\mathrm{PhD}$, Albert studied the Pleistocene fauna from Monte Peglia (Italy), and was faced with the confusing arvicolid taxonomy of the 1970s. In order to solve these problems, he developed a measuring scheme to morphometrically capture the shape of the anterior lobe of the arvicolid $\mathrm{m} 1$. This brought him to Hungary, and the classical fissure fillings in which many species were defined by Kretzoi (Fig. 1). Albert's measurements of the occlusal surface are still standard in vole

This article is a contribution to the special issue "Old worlds, new ideas. A tribute to Albert van der Meulen.”

Lars W. van den Hoek Ostende

Lars.vandenHoekOstende@Naturalis.nl

Pablo Pelaez-Campomanes

pablopelaez@mncn.csic.es

Wilma Wessels

W.Wessels@uu.nl

1 Naturalis Biodiversity Center, Leiden, The Netherlands

2 Departamento de Paleobiología, Museo Nacional de Ciencias Naturales (CSIC), Madrid, Spain

3 Department of Earth Sciences, Utrecht University, Utrecht, The Netherlands taxonomy and the accompanying ratios are these days easily calculated on the computer. However, PCs were not available at that time, and the first application of the 'Van der Meulen method' involved a grocery calculator and many hours of tedious work in a Budapest hotel room, with the assistance of his wife, Joke, his trusted companion in this and many other scientific ventures.

After his $\mathrm{PhD}$, Albert became a lecturer at Utrecht University, a position he held throughout his career. Although he published a number of papers on Pleistocene faunas and supervised two PhDs pertaining to the Quaternary, his attention shifted to older worlds and different areas (Fig. 2). The work with his Utrecht colleagues brought him to the eastern Mediterranean, but also included an epic road trip (!) to Pakistan.

Greece has a special meaning to Albert. A very talented accordion player, his favourite music has its roots in the Balkan area, including 'rebetiko', the 'Greek 'blues'. Thus, his travels to the southern Balkans, often in the company of his family (Fig. 3), were a homecoming. This is perhaps best illustrated by a night in Macedonia, when Albert brought tears to the eyes of the locals by playing Anatolian songs. Much of the population of northern Greece has their roots in Asia Minor, and now this Dutch scientist and his accordion were bringing the songs of the old days back to them.

The most influential paper from that period was probably that on the glirids from Aliveri. Together with his colleague Hans de Bruijn, Albert distinguished ecomorphotypes, thus opening the way for the use of dormice in palaeoenvironmental reconstructions. This paper was also a harbinger of his later work, which more and more focussed on environmental changes.

At the end of the 1980s, Remmert Daams invited Albert to join him in his studies in Spain, and particularly in the area of Daroca-Calatayud, where the type section of the Aragonian lies. It was the beginning of a life-long friendship and a fruitful cooperation, both inside and outside Spain (Fig. 4). In 1992, a 


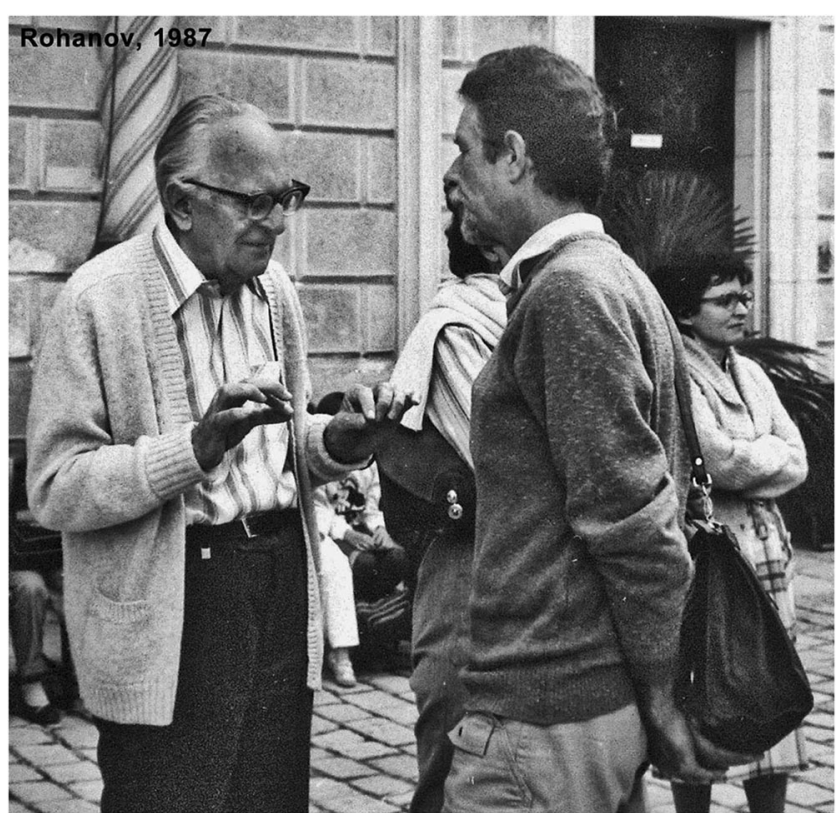

Fig. 1 Albert at the first arvicolid workshop in Rohanov (1987) in discussion with Míklos Kretzoi.

joint paper appeared that demonstrated that the Mid-Miocene Cooling could be recognised in the rodent assemblages of the Aragonian type section using multivariate statistics. The work in Spain also showed that, like no other, Albert was aware that true advance can only be made by a combination of arduous basal palaeontological studies in combination with innovative thinking. A prime example of this is the 2003 revision of the middle-sized cricetids of the Daroca-Calamocha area. This important taxonomical work appeared in a volume in memory of Remmert Daams, who had unexpectedly died in 1999. The loss of his friend was a tremendous personal blow to Albert.

Together with a new generation of Spanish palaeontologists (Fig. 5), Albert continued the work in Spain. In 2005, he led a paper introducing the terms 'transients' and 'residents' in palaeontology. Already a known phenomenon on ecological timescales, Albert and co-workers showed that the same principle applies to deep time. The study resulted from the everincreasing resolution of the fossil record in Daroca-Calatayud, and the continuous improvements in the taxonomy of its faunas. This also allowed the revision and confirmation of the stratigraphy of the area, particularly in combination with palaeomagnetic data. This resulted in two important papers, in which a team led by Albert showed a diachrony in the entrance of rodent taxa in central Europe and Spain, with far-reaching consequences for the biochronology of the European mammal record. Once again, a paper by Albert van der Meulen had changed the scientific landscape.

Publications are the tangible legacy of a scientific career. Still, we would be selling Albert short by assuming that the papers are his greatest legacy. Calling him one of the kindest colleagues in our field is by no means an exaggeration. Perhaps more importantly is that he is a natural-born teacher. His open minded attitude to science was mirrored in his dealings with students and colleagues. Always willing to listen and offering his insights ensured that he could get along with almost everybody, a rare quality in the field. His students were always enticed to look beyond the fossil, to not only recognise patterns but to try and give them meaning, to discover new things about the old worlds of the past.
Fig. 2 One of the first times Albert visited Spain was in 1974, when he attended the Venta del Moro colloquium, where he met many of his future friends.

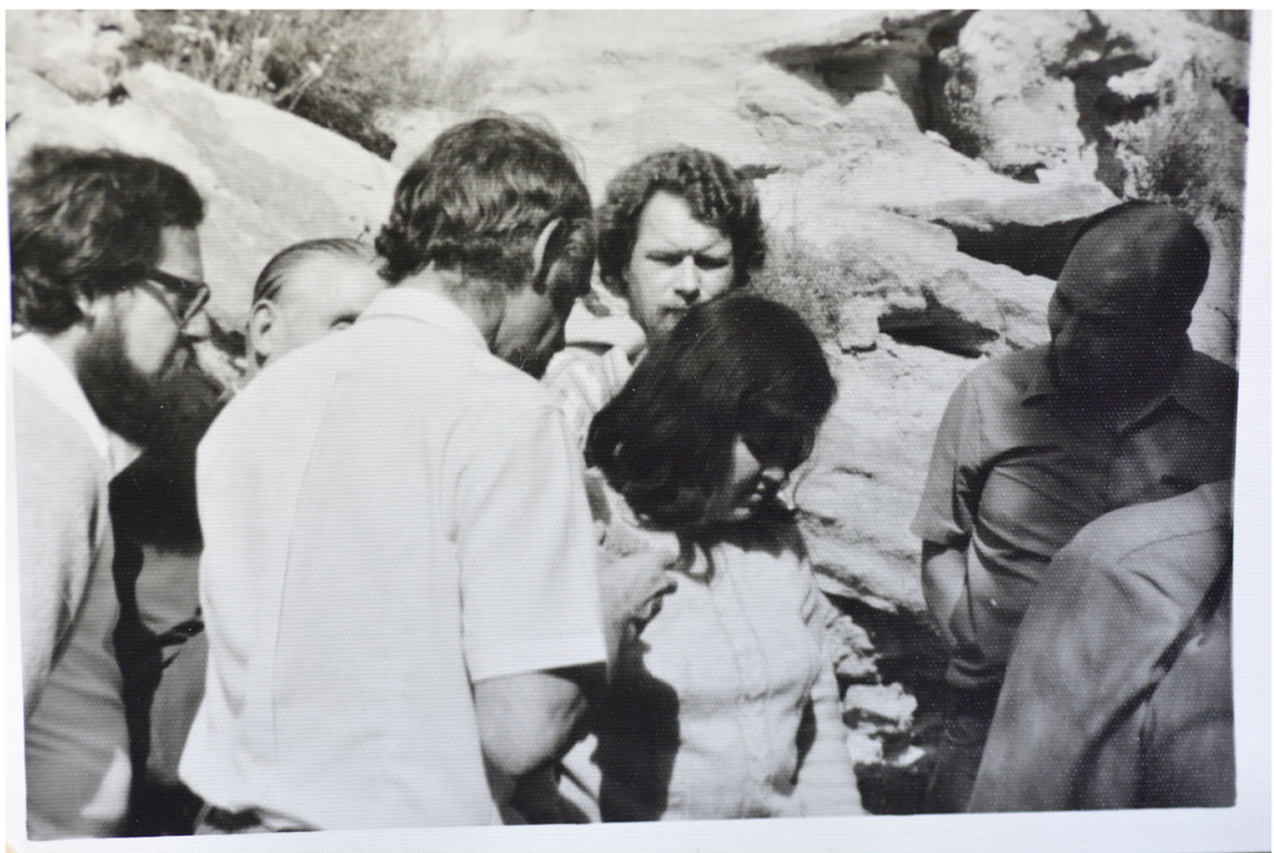


Fig. 3 Albert was often joined in the field by his family. Here, during the 1988 fieldwork in Loranca (Spain), his wife, Joke, is listening as Jorge Morales is in discussion with Albert.

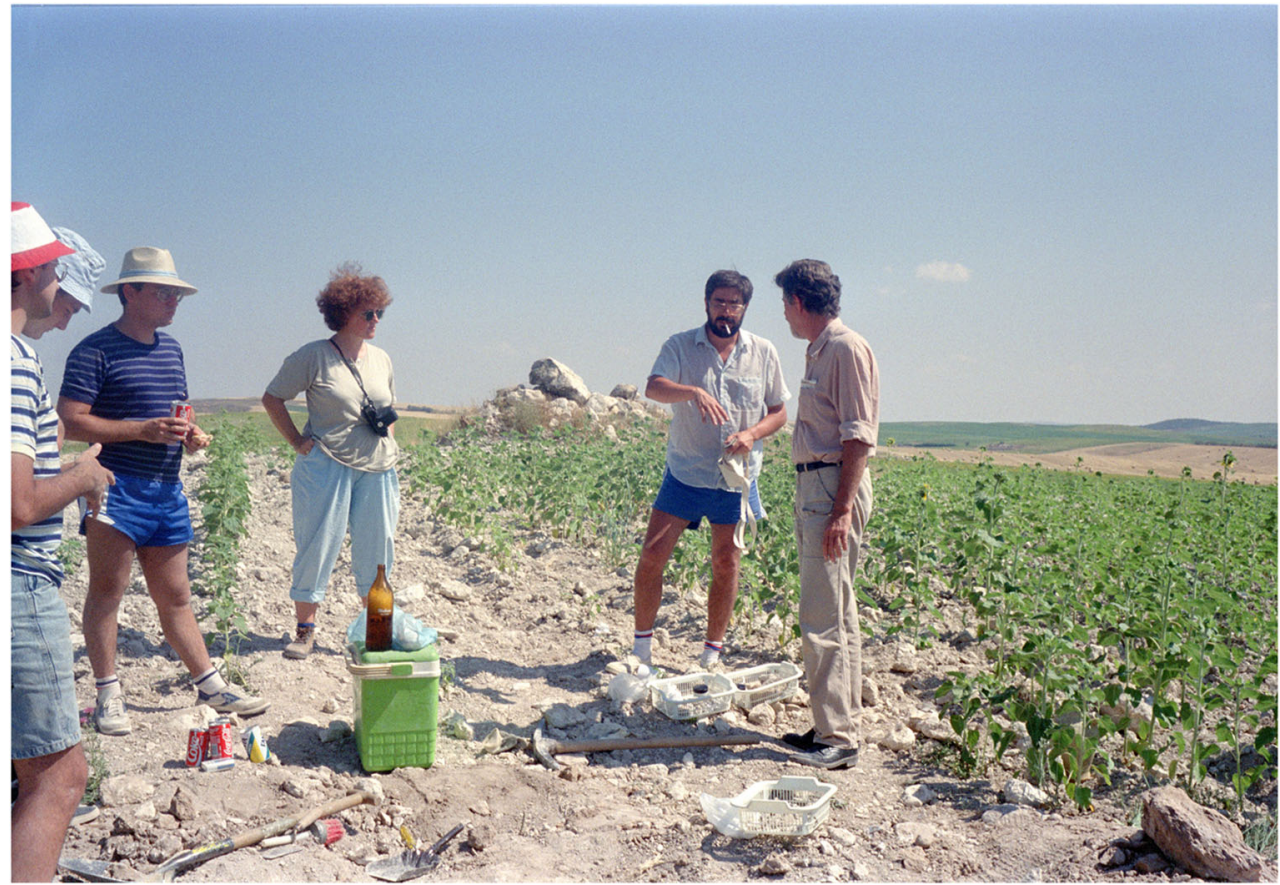

Editing these papers in honour of Albert has been a great pleasure. The enthusiastic offers of manuscripts after the first call made us aware on how well loved Albert is in the field. And while editing the papers, over and over again you realise how important Albert has always been. Many of the papers presented here could not have been written, if it had not been for the scientific legacy of Albert. We thank all the authors for joining us in this venture, and we thank the editors of Palaeobiodiversity and Palaeoenvironments for offering their journal to the friends of Albert. As is clear from

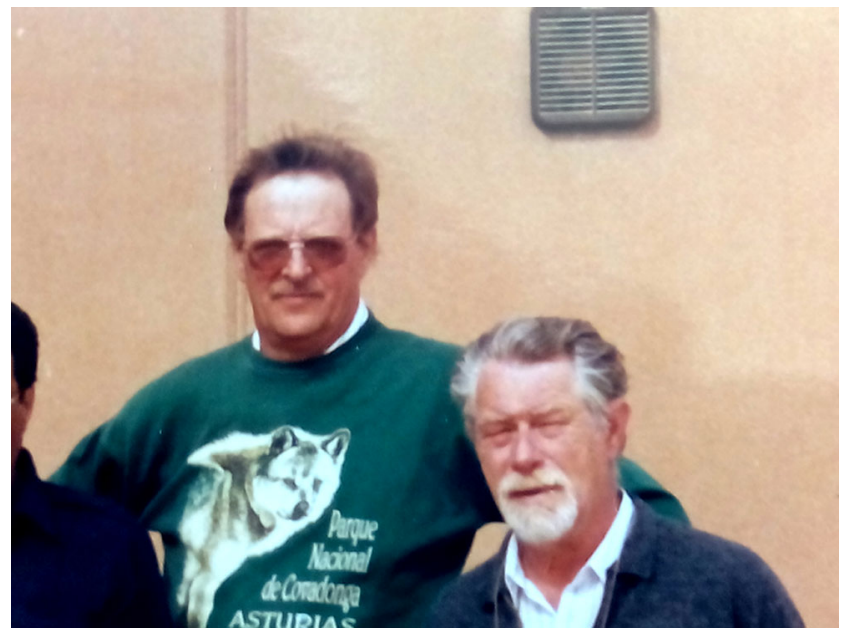

Fig. 4 In 1997, Albert joined Remmert Daams (second on the right standing) in a field work in the Lybian dessert. the listing below, it has become an issue which truly presents new ideas about old worlds.

\section{Robert Martin: "A preliminary diversity-divergence model for North American arvicolid rodents"}

The contribution of Bob Martin to the special issue deals with the first love of Albert, the Arvicolidae. Martin explores the diversity of the North American representatives in comparison with those from the Old World and presents a new model, which allows for the possibility that the present-day voles are polyphyletic. The dense fossil record of Arvicolidae allows for rigorous testing of phylogenies based on genetic material. Some issues, however, remain inconclusive. (Palaeobio Palaeoenv 95(3). Doi: 10.1007/s12549-015-0187-y)

\section{Hans de Bruijn, Anneke A. Bosma and Wilma Wessels "Are the Rhizomyinae and the Spalacinae closely related? Contradistinctive conclusions between genetics and palaeontology"}

The contribution by Albert's colleague Hans de Bruijn and coauthors deals entirely with conflicting evidence from the fossil record and genetics. In this case, based on the fossil record, they challenge the inclusion of the Rhizomyinae within the family of the Spalacidae. The authors are very familiar with that fossil record, as much of the early evolution of the group took place in the early Miocene on a landmass consisting of the southern Balkans and present-day Anatolia, which has been a focus point for the excavations of the group for 
Fig. 5 Albert as Grand Master of a younger generation in the Rambla de Vargas near Daroca in 2008. All colleagues in this photograph are also contributors to the present special issue. From left to right: Israel García Paredes, Lars W. van den Hoek Ostende, Adriana Oliver, Albert van der Meulen, Raquel López Antoñanzas and Pablo PelaezCampomanes

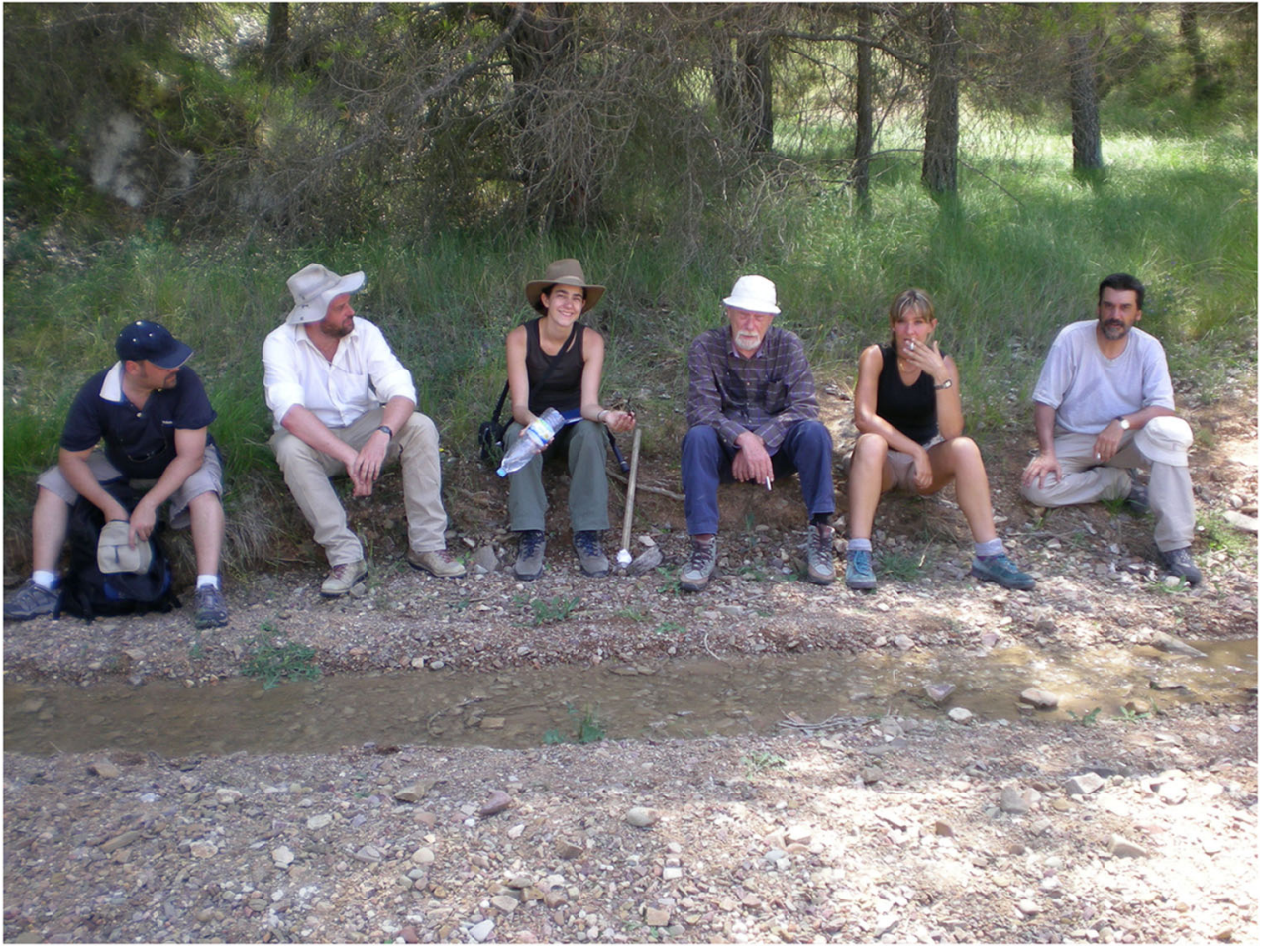

decades. (Palaeobio Palaeoenv 95(3). Doi: 10.1007/s12549015-0195-y)

Lars W. van den Hoek Ostende, Serdar Mayda, Adriana Oliver, Anneke Madern, Veronica Hernández- Ballerín, Pablo Pelaez-Campomanes "Aliveri revisited, a biogeographical appraisal of the early Miocene mammals from the eastern Mediterranean"

The contribution of Van den Hoek Ostende and co-authors also deals with the early Miocene of southeastern Europe. Aliveri is a locality which was excavated by a GreekDutch team including Albert van der Meulen. Its fauna was published in a series of articles in the 1980s. Now, 25 years later, the biogeography of the locality is discussed in view of the present-day knowledge. (Palaeobio Palaeoenv 95(3). Doi: 10.1007/s12549-0150199-7)

George D. Koufos and Katerina Vasileiadou "Miocene/Pliocene mammal faunas of southern Balkans: implications for biostratigraphy and palaeoecology"

George Koufos and Katerina Vasileiadou are responsible for the other contribution dealing with Greece. In an overview of the Turolian/Ruscinian, they demonstrate that the Miocene/Pliocene transition in the area is characterised by a relatively open landscape, with densely forested patches near waterways. This trend towards an increasingly more humid landscape had already started in the Turolian and in surmounts in the lignites from the Pliocene. (Palaeobio Palaeoenv 95(3). Doi: 10.1007/s12549-015-0201-4)

Lars W. van den Hoek Ostende, James D. Gardner, Lysanne Bennekom, M. Cihat Alçiçek, Alsion Murray, Frank P. Wesselingh, Hülya Alçiçek and Alexey Tesakov: "Ericek, a new Pliocene vertebrate locality in the Çameli Basin (southwestern Anatolia, Turkey)"

Van den Hoek Ostende and co-authors show that the humid environments of the Pliocene are also found further east, in Anatolia. The authors base their environmental reconstruction on a variety of different taxa, including mollusc shells, fish pharyngeal teeth, bones of ectothermic tetrapods and molars from small mammals. Together, these lead to the reconstruction of an open, warm lake in forested surroundings. (Palaeobio Palaeoenv 95(3). Doi: 10.1007/s12549-015-0202-3) 
Kees Hordijk, Anneke Bosma, Hans de Bruijn, Jan van Dam, Caspar Geraedts, Jelle Reumer, Wilma Wessels: "Biostratigraphical and paleoecological implications of the small mammal assemblage from the late early Miocene of Montalvos2, Teruel Basin, Spain”

The paper by Albert's former PhD student, Kees Hordijk, and co-authors also gives a comprehensive overview of a locality. Montalvos 2, which was excavated by a team including Albert, gives an unexpected view into the early Miocene of the Teruel Basin, an area mainly known for much younger localities. (Palaeobio Palaeoenv 95(3). Doi: 10.1007/s12549-015-0203-2)

Ana Anchelergues Tarraco, Elvira Martín Suárez and Matthijs Freudenthal: "Muridae (Rodentia) from the early Pleistocene of Loma Quemada-1 (Granada, Spain)”

Tarraco and co-authors use a more restricted approach, and focus on the three murid species from the locality of Loma Quemada 1 in southern Spain, elaborating on the taxonomy. This early Pleistocene locality has recorded one of the youngest occurrences of the genus Castillomys. (Palaeobio Palaeoenv 95(3). Doi: 10.1007/s12549-015-0189-9)

Isaac Casanovas Vilar, Sergio Almécija and David Alba: "Late Miocene flying squirrels from Can Llobateres 1 (Vallès-Penedès Basin, Catalonia): systematics and palaeobiogeography"

The contribution by Isaac Casanovas and co-authors also focuses on a single group from one locality. They elaborate on the flying squirrels from the classical locality of Can Llobateres 1. These rodents are of great palaeoecological and palaeobiogeographical value. On the Iberian Peninsula, they only flourished in the lush forests of Catalonia. (Palaeobio Palaeoenv 95(3). Doi: 10.1007/s12549-0150192-1)

Jorge Morales, Juan L. Cantalapiedra, Alberto Valenciano, Daniel Hontecillas, Susana Fraile, Blanca A. García Yelo, Plinio Montoya and Juan Abella: "The fossil record of the Neogene Carnivore Mammals from Spain"

The author group led by Albert's good friend Jorge Morales also deals with a single group. This team of Spanish specialists in carnivores presents a comprehensive overview of the Neogene representatives in Spain. Their diversification patterns show four episodes of origination and an equal number of periods of extinctions. (Palaeobio Palaeoenv 95(3). Doi: DOI 10. 1007/s12549-015-0206-z)

Manuel Hernández Fernández, Juan $L$. Cantalapiedra, Ana Rosa Gómez-Cano: "Plio-Pleistocene climatic change had a major impact in the assembly and disassembly processes of Iberian rodent communities"

The contribution of Manuel Hernández Fernández and co-authors presents a bird's eye view of the late Neogene and Quaternary rodent assemblages of Spain. They recognise five associations of genera, the succession of which seems to be mainly governed by climatic changes. (Palaeobio Palaeoenv 95(3). Doi: 10.1007/s12549015-0196-x)

Pablo Pelaez-Campomanes, Veronica HernándezBallerín, Adriana Oliver: "New approaches to examining and interpreting patterns of dental morphological variability in Miocene cricetids"

Among all the contributions from Spain, there are two dealing with Albert's own fieldwork area. In fact, the paper by Pablo Pelaez-Campomanes et al. is a continuation of the review of the Democricetodon written by Albert, Remmert and Pablo. In this new contribution, the authors demonstrate a correlation between morphological variability and the abundance of taxa being studied. Periods of increased change can be correlated with known climatic changes. (Palaeobio Palaeoenv 95(3). Doi: 10.1007/ s12549-015-0198-8)

Paloma López-Guerrero, Israel García-Paredes, Jérôme Prieto, Raquel López-Antoñanzas and M. Ángeles Álvarez-Sierra: "Palaeodiversity of Cricetodontini during the late Aragonian (middle Miocene) from the European basins"

The paper by López-Guerrero and co-workers explores a pattern in the evolution of the Cricetodontini that was first recognised in the late middle Miocene sequence of the Calatayud-Daroca Basin. The pattern found here, in which basal forms are succeeded by a variety of endemic taxa showing a mosaic of characters, is also recognised in other European basins, up to and including the late Badenian-early Pannonian series in Hungary. (Palaeobio Palaeoenv 95(3). Doi: 10.1007/s12549015-0209-9 
Jérôme Prieto, Lars W. van den Hoek Ostende, János Hír and László Kordos: "The Middle Miocene insectivores from Hasznos (Hungary, Nógrád County)"

One of the Hungarian sites discussed by López-Guerrero et al. is also the subject of the contribution by Jérôme Prieto and coworkers. It confirms that Hungary has more to offer than the classical Pleistocene sites studied by Albert for his $\mathrm{PhD}$. Hasznos was the first pre-Pannonian site to be discovered. Its insectivores provide tantalizing biogeographical ideas, as the assemblage contains elements of eastern origin. (Palaeobio Palaeoenv 95(3). Doi: 10.1007/s12549-015-0193-0)

Lars W. van den Hoek Ostende and Oldrich Fejfar: "All time high: Dimylidae (Eulipotyphla, Mammalia) diversity in the early Miocene locality of Ahníkov 1 (Czech Republic, MN 3)"

Another insectivore contribution from eastern Europe is presented by Van den Hoek Ostende and Fejfar. They discuss the Dimylidae from the early Miocene Czech locality of Ahníkov 1. Although the family is known to have had its largest diversity in central Europe, never before were four different species found in one locality. One of the Ahníkov species represents a new genus and species, Lacrimodon vandermeuleni gen. nov, sp. nov. (Palaeobio Palaeoenv 95(3). Doi: 10.1007/s12549015-0210-3

Marguerite Hugueney, Olivier Maridet, Pierre Mein, Cécile Mourer-Chauviré and Jérôme Priéto "Lartetium africanum (Lavocat, 1961) (Eulipotyphla • Soricidae) from Beni-Mellal (Morocco), the oldest African shrew: new descriptions, palaeoenvironment and comments on biochronological context"
The third insectivore contribution comes from Marguerite Hugueney and co-authors and takes us to the other side of the Mediterranean. Their description of Lartetium from northern Africa not only has interesting biogeographical consequences, but also clarifies much about the taxonomy of this otherwise European genus. (Palaeobio Palaeoenv 95(3). Doi: 10.1007/s12549-015-0197-9)

Jelle S. Zijlstra and Lawrence J. Flynn: "Hedgehogs (Erinaceidae, Lipotyphla) from the Miocene of Pakistan, with description of a new species of Galerix "

Although Albert never actually published on Pakistan, he may well have excavated some of the fossils in this contribution. Jelle Zijlstra and Larry Flynn have combined data from Pakistan fossils in American and Dutch collections, and present an overview of the sequence, including a new species of the gymnure Galerix, G. wesselsae nov. sp. (Palaeobio Palaeoenv 95(3). Doi: 10.1007/s12549-015-0190-3)

Elisa Locatelli, Rokus Awe Due, Jatmiko, Lars W. van den Hoek Ostende "Middle size murids from Liang Bua (Flores, Indonesia): insular endemics, human introductions and palaeoenvironment"

The final contribution, by Elisa Locatelli and co-workers, deals with fossils from Indonesia, the country where Albert was born and where he himself collected rodents. The fossils described by Locatelli et al. come from the late Pleistocene and Holocene of Flores, and mainly stem from the endemic rats Komodomys and Paulamys. But the entrance of commensal rats is also recognised in the sequence, and seems to coincide with a period of relative drought. (Palaeobio Palaeoenv 95(3). Doi: 10.1007/s12549-015-0204-1) 